\title{
Effect of Sparassis crispa Extracts on Immune Cell Activation and Tumor Growth Inhibition
}

\author{
In-Kyu Kim¹, Young Chul Yun², Yong Chul Shin ${ }^{2}$ and Jiyun Yoo ${ }^{1 *}$ \\ ${ }^{1}$ Department of Microbiology/Research Institute of Life Science, College of Natural Sciences, Gyeongsang National University, Jinju 660-701, Korea \\ ${ }^{2}$ Amicogen Inc, Jinsung, Jinju 660-852, Korea
}

Received May 20, 2013 /Revised August 6, 2013 /Accepted August 8, 2013

\begin{abstract}
Sparassis crispa is an edible mushroom with medicinal properties that contains more than $40 \% \beta$ glucan. The role of $S$. crispa in regulating the functional activation of macrophages has yet to be fully elucidated. The objective of this study was to investigate the molecular mechanism underlying the immune-stimulatory function of $S$. crispa soluble $\beta$-glucan and extracts on macrophages. In this study, we showed that $S$. crispa soluble $\beta$-glucan was able to stimulate TNF-a and IL-1 $\beta$ production through NF-kB activation in Raw 264.7 cells. We also showed that $S$. crispa extracts could not only enhance TNF-a production in Raw 264.7 cells, but also suppress tumor growth in vivo. All of our results suggest that $S$. crispa could be developed as a promising immunostimulatory principle, applicable to cancer patients.
\end{abstract}

Key words : Sparassis crispa, TNF-a, IL-1ß, NF-kB, tumor growth

\section{서 론}

천연물 유래 생리활성 물질의 탐색은 선진국을 중심으로 세계 각국에서 활발히 이루어지고 있으며, 특히 버섯으로부터 추출한 생리활성 물질이 면역증강 및 항암효과를 나타낸다는 것이 보고되면서 버섯에서 추출한 성분을 이용한 면역증강 및 항암효과에 대한 연구가 활발히 진행되고 있다. 버섯은 탄 수화물, 단백질, 지질, 무기질 및 비타민 등 풍부한 영양과 독 특한 향을 가지고 있어 기호식품으로 널리 알려져 있으며, 특 히 항산화 효과, 항암 효과, 혈당 강화, 콜레스테롤 저하 등의 효과가 뛰어나 예로부터 약용으로 널리 이용되고 있다 $[4,7$, $10,12,19,20]$. 일반적으로 버섯의 자실체에서 추출한 다당류 는 유방암이나 대장암의 증식을 억제하는 등 항암효과가 우수 하지만 암세포에 직접 작용하기보다는 면역체계의 대식세포 를 활성화시켜 치료효과를 나타내기 때문에 부작용을 거의 나타내지 않는다고 알려져 있다[1, 2, 21]. 또한 암의 치료에 사용되는 일반적인 항암화학요법제와 병용하는 경우 항암제 에 대한 부작용을 완화시켜 그 치료 효과를 증가시킬 수 있다 는 보고들이 있다[5].

꽃송이버섯(Sparassis crispa) 은 민주름버섯목, 꽃송이버섯 과에 속하는 버섯으로[9], 한국, 일본, 중국, 유럽, 북아메리카,

\footnotetext{
*Corresponding author

Tel : +82-55-751-5947, Fax: +82-55-759-5199

E-mail: yooj@gsnu.ac.kr

This is an Open-Access article distributed under the terms of the Creative Commons Attribution Non-Commercial License (http://creativecommons.org/licenses/by-nc/3.0) which permits unrestricted non-commercial use, distribution, and reproduction in any medium, provided the original work is properly cited.
}

호주 등에 널리 분포되어 있으며, 우리나라에서는 5월부터 발 생하기 시작하여 7-8월에 가장 많이 발견되고 9월까지 소나무, 잣나무, 낙엽송, 전나무 등 침엽수에 발생한다고 알려져 있다 [13]. 꽃송이버섯은 특히 면역증강 및 항암 효과가 뛰어나다고 알려져 있는 베타-글루칸의 함량이 건조중량의 $40 \%$ 이상인 것으로 보고되고 있어 이를 이용한 건강기능성 식품개발의 기대가 큰 버섯이다[14]. 꽃송이버섯에는 베타-글루칸과 더불 어 다양한 phenolic compound가 많이 함유되어 있는데, 그 중 veratric acid와 같은 benzoic acid 계열의 성분을 다른 약용 버섯에 비해 많이 함유하고 있는 것으로 보고되고 있다[8]. Benzoic acid 계열 중 하나인 veratric acid는 항산화 기작과 더불어, 인위적으로 고혈압이 유도된 마우스에게 경구투여 하 였을 때, nitric oxide $(\mathrm{NO})$ 의 농도는 증가시키고, 산화 스트레 스를 감소시켜 혈압을 조절하는 것으로 알려져 있다[16].

일반적으로 버섯에서 추출한 베타-글루칸의 면역활성 및 항암 효과는 널리 알려져 있는 반면 꽃송이버섯 유래의 베타글루칸에 의한 대식세포의 활성화 기작 및 자실체 추출물에 의한 항암 효과는 아직 보고되지 않았다. 따라서 본 연구에서 는 꽃송이버섯 유래 베타-글루칸의 면역활성 효과를 확인하고 자 마우스의 대식세포인 Raw 264.7 cell을 이용하여 베타-글루

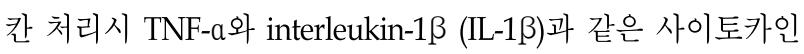
의 발현 및 분비량을 확인하였고, 꽃송이버섯 추출물의 항암 효과를 in vivo에서 검증하였다.

\section{재료 및 방법}

\section{꽃송이버섯 유래 베타-글루칸의 추출}

꽃송이버섯 $50 \mathrm{~g}$ 을 갈아 분말화한 후 물 21 를 첨가하여 
$121^{\circ} \mathrm{C}$ 에서 10 시간 동안 열수 추출을 실시하였다. 그 후 8,000 $\mathrm{rpm}, 4^{\circ} \mathrm{C}$ 에서 20 분 동안 원심분리 후 상등액을 회수하고 $80 \%$ 에탄올을 첨가하여 다당체를 침전시킨 후 $55^{\circ} \mathrm{C}$ 에서 12 시간 동안 건조하여 열수 추출물을 획득하였다. 열수 추출된 베타글루칸 시료에 a-amylase, cellulose, protease, amyloglucosidase 등으로 효소분해를 실시하여 베타-글루칸 이외의 알파글루칸과 단백질 등을 분해한 후 에탄올로 침전시켜 효소분해 되지 않은 베타-글루칸을 회수하여 동결 건조 하였다. 베타-글 루칸을 정량하기 위해서는 동결 건조한 베타-글루칸을 산 가 수분해하여 유리되는 총 포도당 함량을 계산하였다[15, 17].

\section{세포 배양}

마우스의 대식세포주인 Raw 264.7 cell은 한국세포주은행 (KCLB)에서 분양 받아 $10 \%$ fetal bovine serum (FBS, Gibco, Invitrogen)와 $1 \%$ penicillin-streptomycin을 포함하는 Dulbecco's modified Eagle medium (DMEM) 배지를 사용하여 $37^{\circ} \mathrm{C}, 5 \% \mathrm{CO}_{2}$ 조건에서 배양하였다.

\section{사이토카인 측정}

마이크로플레이트(Corning Laboratory Science Co., NY, USA)의 각 well에 $1 \times 10^{6}$ 의 세포가 들어가도록 분주한 후 꽃송 이버섯에서 추출한 베타-글루칸을 여러 가지 농도로 처리하고 24시간 후 Bio Plex (Bio rad)를 이용하여 TNF- $a$ 와 IL-1 $\beta$ 를 측정하였다. 측정 방법을 간략하게 소개하면, $1 \% \mathrm{BSA}$ 가 함유 된 PBS 100 lㅣㄹㅗ 각 well을 적신 후, standard, sample, reference와 blank 시약을 각 $100 \mu \mathrm{l}$ 씩 분주한 후 상온에서 30 분간 shaking을 하며 배양하였다. $1 \%$ BSA와 $0.05 \%$ Tween20이 함 유된 PBS $150 \mu 1$ 로 3 번 세척한 후, 혼합된 Biotinylated Abs를 well당 $50 \mu 1$ 씩 분주하고, 30 분간 shaking을 하며 상온에서 배양하였다. 3 번 세척 후 streptavidin-PE를 넣어준 후 10 분간 배양하고, 3 번 세척 후 $1 \% \mathrm{BSA}$ 와 $0.05 \%$ Tween 20이 함유된 PBS $120 \mu 1$ 를 분주한 후 Bio-Plex array reader를 이용하여 측 정하였다.

\section{$\mathrm{RNA}$ 분리 및 $\mathrm{RT}-\mathrm{PCR}$ 분석}

RNA 분리를 위해서는 total RNA isolation system (Promega)을 사용하였다. 분리한 RNA를 $260 \mathrm{~nm}$ 에서 UV-visible spectrophotometer를 이용하여 정량 한 후 Maxime RT-PCR Premix kit (Intron, Korea)를 사용하여 RT-PCR을 수행하였다. 세포에서 분리한 total RNA $250 \mathrm{ng}$ 에 각각의 유전자에 특이적 인 primer를 20 pmole씩 첨가한 후 RNase-free water로 전체 volume이 $20 \mu 1$ 가 되게 하였다. 이 혼합물을 Maxime RT-PCR Premix와 섞은 후 $45^{\circ} \mathrm{C}$ 에서 30 분간 reverse transcription 반 응 후 $94^{\circ} \mathrm{C}$ 에서 5 분 간 가열하여 reverse transcriptase의 활성 을 없애고PCR 반응을 수행하였다. $\mathrm{PCR}$ 은 $94^{\circ} \mathrm{C}$ 에서 45 초, $72^{\circ} \mathrm{C}$ 에서 45 초로 25 회 반복 반응하였다. 얻어진 PCR product를 $1.5 \%$ agarose gel에서 전기영동 한 후, ethidium bro-
Table 1. Primer sequences used for RT-PCR analyses

\begin{tabular}{|c|c|c|}
\hline $\begin{array}{l}\text { Name of } \\
\text { Gene }\end{array}$ & Direction & Nucleotide sequences \\
\hline TNF- $a$ & $\begin{array}{l}\text { Sense } \\
\text { Antisense }\end{array}$ & $\begin{array}{l}\text { 5'-ATGAGCACTGAAAGCATGATC-3' } \\
5^{\prime} \text {-TTATCTCTCAGCTCCACGCCA-3' }\end{array}$ \\
\hline IL-1 $\beta$ & $\begin{array}{l}\text { Sense } \\
\text { Antisense }\end{array}$ & $\begin{array}{l}\text { 5'-GACACATGGATAACGAGGCT-3' } \\
5^{\prime} \text {-TTAGGAAGACACAAATTGCAT-3' }\end{array}$ \\
\hline$\beta$-actin & $\begin{array}{l}\text { Sense } \\
\text { Antisense }\end{array}$ & $\begin{array}{l}\text { 5'- GTGGGGCGCCCCAGGCACCA-3' } \\
5^{\prime} \text { - CTCCTTAATGTCACGCACGAT-3 }\end{array}$ \\
\hline
\end{tabular}

mide로 염색하여 각 유전자들의 발현 정도를 확인하였다. 실 험에 사용한 각 유전자에 특이적인 primer sequence는 Table 1 에 기술하였다.

\section{Transfection 및 NF-kB luciferase activity 측정}

Transfection 24 시간 전에 $2 \times 10^{5}$ 개의 Raw 264.7 cell을 6well plate에 분주한다. Fugene 6 를 이용하여 NF-kB Luciferase Reporter 유전자를 세포에 transfection하고, 24시간 후 medium을 교체하면서 여러 가지 농도의 베타-글루칸을 처리하 고 24 시간 후 luciferase activity를 측정하였다.

\section{Tumor growth 측정}

꽃송이버섯 추출물에 의한 tumor growth 억제를 확인하기 위해 $1 \times 10^{6}$ 개의 murine B16F10 melanoma세포를 C57BL/6J mouse의 복강에 주사하여 암을 발생시켰으며, B16F10 세포를 주사하기 7일 전부터 매일 $200 \mathrm{mg} / \mathrm{kg}$ 으로 꽃송이버섯 추출물 을 먹이면서 mouse의 tumor volume을 21일 간 측정하였다. Tumor volume은 가로 $\times$ 세로 $\times$ 높이 $\times 1 / 2$ 로 측정하였다.

\section{결과 및 고찰}

\section{꽃송이버섯에서 추출한 베타-글루칸의 면역활성 효과 검증}

꽃송이버섯에서 추출한 베타-글루칸의 면역활성 효과를 검 증하기 위해 마우스 대식세포인 Raw 264.7 cell을 사용하여 베타-글루칸을 처리하였을 때 사이토카인인 TNF- $a$ 와 interleukin-1 $\beta$ (IL-1 $\beta$ )의 분비량을 측정하였다. 대식세포는 항원의 자극을 받아 활성화되면 TNF-a, IL-13, IL-6, IL12, 그리고 GM-CSF 등을 분비하여 면역 반응을 조절한다. TNF-a는 종양 괴사인자(Tumor Necrosis Factor)로 알려질 물질로 종양세포 를 파괴시키는 사이토카인이며, IL-1 $\beta$ 는 국소 염증반응을 매 개하며 혈과 내피세포에 작용하여 백혈구의 부착을 매개하는 표면 분자의 발현을 증가시키는 사이토카인이다. 따라서 꽃송 이버섯에서 추출한 베타-글루칸이 대식세포를 활성화시켜 이 들 사이토카인의 분비에 어떠한 영향을 미치는지 확인하였다. 배양한 Raw $264.7 \mathrm{cell}$ 에 여러 가지 농도의 베타-글루칸을 처 리한 결과 처리한 베타-글루칸의 농도에 비례하여 TNF-a의 

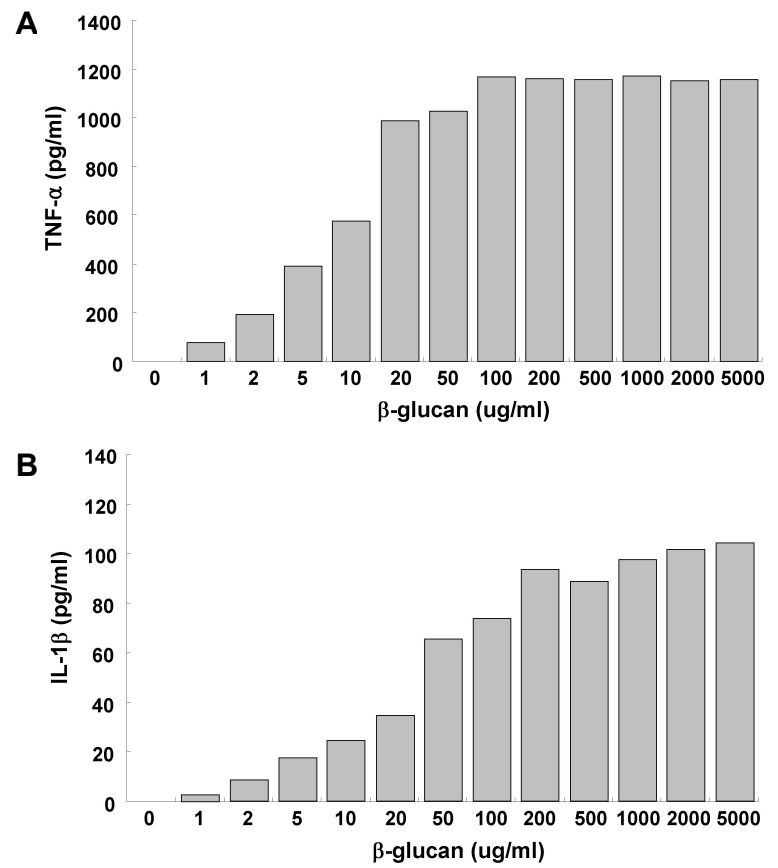

Fig. 1. Effect of beta-glucan prepared from $S$. crispa on the production of TNF-a and IL-1ß. (A) Raw 264.7 cells were treated with indicated amounts of beta-glucan prepared from $S$. crispa for $24 \mathrm{~h}$. TNF-a (A) and IL-1ß (B) in supernatant of incubated cells were measured.

분비가 증가함을 알 수 있었으며, $100 \mu \mathrm{g} / \mathrm{ml}$ 의 농도에서 최대 의 분비량을 나타냄을 확인하였다(Fig. $1 \mathrm{~A})$. IL-1ß의 분비 또 한 처리한 베타-글루칸의 농도에 비례하여 증가하였으며, 200 $\mathrm{\mu g} / \mathrm{ml}$ 의 농도에서 최대의 분비량을 나타냄을 확인하였다 (Fig. 1B). 이와 유사한 실험으로 꽃송이버섯에서 추출한 베타글루칸을 처리 후 TNF- $a$ 와 IL-1 $\beta$ 유전자의 발현이 증가되는 지 RT-PCR을 통해 검증하였는데, $10 \mu \mathrm{g} / \mathrm{ml}$ 의 베타-글루칸을 처리하였을 때에도 TNF- $\alpha$ 와 IL- $1 \beta$ 의 mRNA가 증가됨을 확인 할 수 있었다(Fig. 2). 이러한 결과들을 통해 꽃송이버섯 추출 물뿐만 아니라 꽃송이버섯에서 추출한 베타-글루칸이 뛰어난 앞선 연구들에서 보고된 바와 같이 대식세포의 면역활성을 촉진시킬 수 있음을 확인할 수 있었다[3, 6, 11].

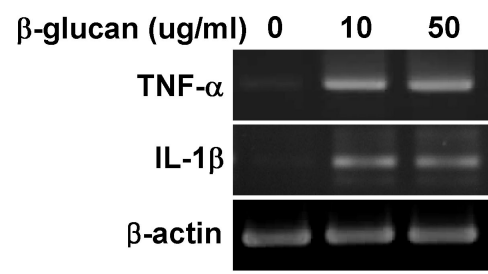

Fig. 2. Effect of beta-glucan prepared from $S$. crispa on the mRNA expression of the TNF- $a$ and IL-1 $\beta$. Raw 264.7 cells were treated with indicated amounts of beta-glucan prepared from $S$. crispa for $24 \mathrm{~h}$. RT-PCR was performed with specific primer for each gene.

\section{꽃송이버섯에서 추출한 베타-글루칸에 의한 NF-kB 활성 증가 확인}

일반적으로 대식세포가 활성화될 때 외부자극에 의해 염증 반응의 전사인자인 NF-kB가 활성화되어 우선적으로 TNF-a, IL-1B, IL-6, 그리고 IL-8과 같은 주요 염증촉진 단백질들의 유 전자 발현을 조절하는 것으로 알려져 있다. 꽃송이버섯에서 추출한 베타-글루칸에 의해 TNF- $a$ 와 IL- $1 \beta$ 의 분비가 증가함 을 확인하였으므로, 이후에는 베타-글루칸에 의해 전사인자인 $\mathrm{NF}-\mathrm{kB}$ 가 활성화되는지 확인하고자 하였다. 이를 위해서는 $\mathrm{NF}-\mathrm{kB}$ 가 활성화되어 핵으로 이동하였을 때 결합하는 DNA 서열을 포함하고 있는 NF-kB Luciferase reporter construct를 이용하였는데, 꽃송이버섯에서 추출한 베타-글루칸을 대식세 포인 Raw 264.7 cell에 처리하였을 때 Luciferase activity가 증가됨을 확인함으로 전사인자인 NF-kB가 활성화되었음을 알 수 있었다(Fig. 3). 이러한 결과들은 꽃송이버섯에서 추출한 베타-글루칸은 염증반응의 전사인자인 NF-kB의 활성화를 통 해 TNF-a나 IL-1 $\beta$ 와 같은 사이토카인의 발현 및 분비를 촉진 시킬 수 있음을 의미하는 것이다.

\section{꽃송이버섯 추출물의 면역활성 효과 검증}

본 연구와 함께 이전의 많은 보고에서도 꽃송이버섯에서 추출한 베타-글루칸이 면역활성 효과와 이를 통한 항암 효과 가 있다는 보고들이 있어왔다[6,11]. 본 연구에서는 베타-글루 칸뿐만 아니라 꽃송이버섯 자실체 추출물 자체도 대식세포의 면역활성 효과가 있는지 검증하고자 하였다. 베타-글루칸의 추출을 위해 준비하였던 꽃송이버섯 열수 추출물 역시 대식세 포의 면역활성 효과가 있는지 확인하고자 Raw 264.7 cell에 여러 가지 농도의 추출물을 처리한 결과 베타-글루칸과 마찬 가지로 처리한 농도에 비례하여 TNF- $a$ 의 분비가 증가함을 알 수 있었으며, 약 $160 \mu \mathrm{g} / \mathrm{ml}$ 의 농도에서 최대의 분비량을 나타

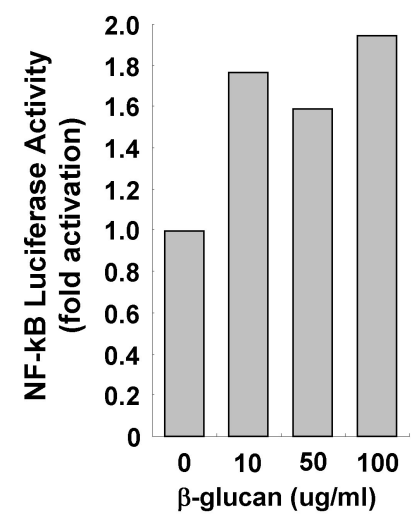

Fig. 3. Effect of beta-glucan prepared from $S$. crispa on the NF-kB activity. Raw 264.7 cells were transfected with NF-kB luciferase reporter construct, and measured luciferase activity after treatment with indicated amounts of beta-glucan prepared from S. crispa for $24 \mathrm{~h}$. 


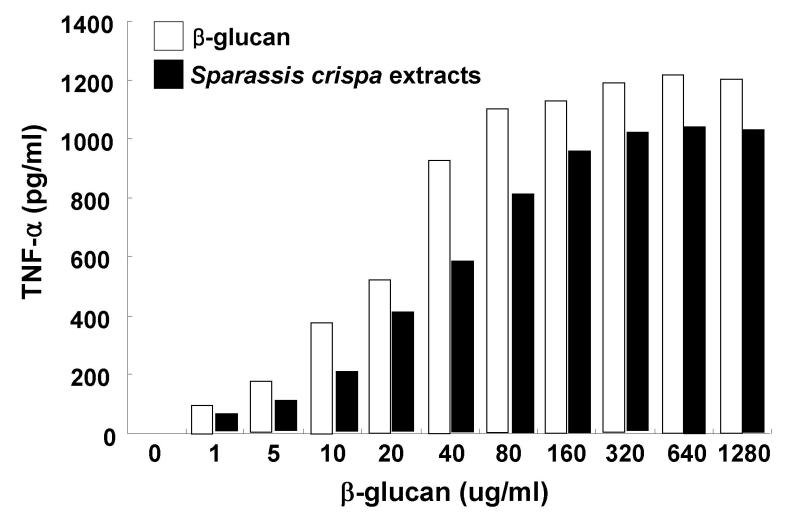

Fig. 4. Effect of $S$. crispa extracts on the production of TNF-a. Raw 264.7 cells were treated with indicated amounts of S. crispa extract for $24 \mathrm{~h}$. TNF-a in supernatant of incubated cells were measured.

냄을 확인하였다(Fig. 4). 이러한 결과는 꽃송이버섯 추출물 역시 베타-글루칸과 마찬가지로 면역활성을 촉진시킴으로 대 식세포의 활성화를 유도할 수 있음을 의미하는 것이다.

\section{꽃송이버섯 추출물의 항암효과 검증}

꽃송이버섯 유래 베타-글루칸의 경우 면역세포의 활성화를 통해 암세포의 성장 및 전이를 억제한다는 보고들이 많이 있 다. 본 연구에서는 꽃송이버섯 추출물 역시 면역세포의 활성 화를 유도함을 확인하였기 때문에 이후에는 이 추출물이 in vivo에서 암세포의 성장을 억제할 수 잇는지 확인하고자 하였 다. 이를 위해서 in vivo에서 암을 잘 유발한다고 알려져 있는 murine B16F10 melanoma세포를 C57BL/6J mouse의 복강에 주사하여 암을 발생시켰으며, B16F10 세포를 주사하기 7일 전 부터 매일 $200 \mathrm{mg} / \mathrm{kg}$ 으로 꽃송이버섯 추출물을 먹이면서 mouse의 tumor volume을 21일 간 측정하였다. 그 결과 PBS 를 먹인 control mouse의 경우 B16F10 세포를 주사한 지 15일 이후부터 급격하게 tumor의 volume이 증가하였지만 꽃송이 버섯 추출물을 먹인 mouse의 경우 tumor의 volume이 증가하 지 않음을 확인할 수 있었다(Fig. 5). 기존의 결과를 통해 꽃송 이버섯 유래 베타-글루칸이 in vivo에서 항암 활성이 있음이

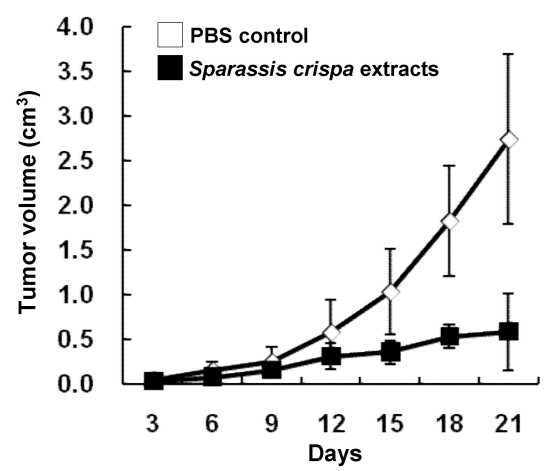

Fig. 5. Effect of $S$. crispa extracts on the primary tumor growth.
알려져 있지만 본 연구를 통해 꽃송이버섯 추출물 역시 암세 포의 성장을 in vivo에서 억제할 수 있음을 확인하였다[22].

꽃송이버섯은 면역증강 및 항암 효과가 뛰어나다고 알려져 있는 베타-글루칸의 함량이 높은 버섯이다. 베타-글루칸뿐만 아니라 $\mathrm{K}, \mathrm{P}, \mathrm{Na}, \mathrm{Mg}$ 등과 같은 미네랄 및 vitamin $\mathrm{E}, \mathrm{C}, \mathrm{D}_{3}$ 와 같은 비타민의 함량이 높아[18] 향후 배양 기간과 자실체 생육 기간의 단축을 통해 대량의 인공재배가 가능해 진다면 꽃송이 버섯을 이용한 의약품 및 건강 기능성 식품의 개발 가능성이 높아질 수 있을 것이다.

\section{감사의 글}

본 연구는 지식경제부 지역산업기술개발사업과제(과제명: 꽃송이버섯 유래 면역증강, 항암 소재의 경제적 생산기술 개 발, 과제번호: 70011463)의 연구비 지원에 의해 수행되었습니 다. 이에 감사를 드립니다.

\section{References}

1. Bano, Z. and Rajarathnam, S. 1988. Pleurotus mushrooms. Part II. Chemical composition, nutritional value, post-harvest physiology, preservation, and role as human food. Crit Rev Food Sci Nutr 27, 87-158.

2. Choi, S. J., Lee, Y. S., Kim, J. K., Kim, J. K. and Lim, S. D. 2010. Physiological activation of extract from edible mushrooms. J Korean Soc Food Sci Nutr 39, 1087-1096.

3. Choi, W. S., Shin, P. G., Yoo, Y. B., Noh, H. J. and Kim, G. D. 2013. Anti-inflammatory effects of Sparassis crispa extracts. J Mushroom Sci Production 11, 46-51.

4. Food Code. 2003. Conduct Laboratory Testing According to Specifications and Test Methods of the Food Code. Pp. 894-918, Korea Food \& Drug Administration, Moon Yong Press, Seoul.

5. Fukuda, K., Uematsu, T., Hamada, A. and Akiya, S. 1975. The polysaccharide from Lampteromyces Japonicus. Chem Pharm Bull 23, 1955-1961.

6. Harada, T., Miura, N. N., Adachi, Y., Nakajima, M., Yadomae, T. and Ohno, N. 2002. IFN- $\gamma$ induction by SCG, 1,3-B-D-glucan from Sparassis crispa, in DBA/2 mice in vitra J Interferon Cytokine Res 22, 1227-1239.

7. Hong, J. S., Kim, Y. H., Kim, M. K., Kim, Y. S. and Sohn, H. S. 1989. Contents of free amino acids and total amino acids in Agaricus bisporus, Pleurotus ostreatus and Lentinus edodes. Korean J Food Sci Technol 21, 58-62.

8. Kim, M. Y., Seguin, P., Ahn, J. K., Kim, J. J., Chun, S. C., Kim, E. H., Seo, S. H., Kang, E. Y., Kim, S. L. and Park, Y. J. 2008. Phenolic compound concentration and antioxidant activities of edible and medicinal mushrooms from Korea. J Agr Food Chem 56, 7265-7270.

9. Kirk, P. M., Cannon, P. F., David, J. C. and Stalpers, J. A. 2001. Ainsworth \& Bisby's Dictionary of the Fungi. Ninth edition. CABI Bioscience. 
10. Lee, S. K., Yoo, Y. J. and Kim, C. S. 1994. Studies on the chemical components in Ganoderma lucidum Korean J Food Sci Technol 21, 890-894.

11. Lee, S. Y., Lee, Y. G., Byeon, S. E., Han, S., Choi, S. S., Kim, A. R., Lee, J., Lee, S. J., Hong, S. and Cho, J. Y. 2010. Mitogen activated protein kinases are prime signalling enzymes in nitric oxide production induced by soluble $\beta$-glucan from Sparassis crispa. Arch Pharm Res 33, 1753-1760.

12. Lee, Y. S., Kim, J. B., Shin, S. R. and Kim, N. W. 2006. Analysis of nutritional components of Lepista nuda. Korean J Food Preserv 13, 375-381.

13. Oh, D. S., Park, J. M., Park, H., Ka, K. H. and Chun, W. J. 2009. Site characteristics and vegetation structure of the habitat of cauliflower mushroom (Sparassis crispa). Korean J Mycol 37, 33-40.

14. Ohno, N., Miura, N. N., Nakajima, M. and Yadomae, T. 2000. Antitumor 1,3-beta-glucan from cultured fruit body of Sparassis crispa. Biol Pharm Bull 23, 866-872.

15. Park, H. G., Shim, Y. Y., Choi, S. O. and Park, W. M. 2009. New method development for nanoparticle extraction of water-soluble beta-(1-3)-D-glucan from edible mushrooms, Sparassis crispa and Phellinus linteus. J Agric Food Chem 57, 2147-2154

16. Raja, B. 2011. Veratric acid, a phenolic acid attenuates blood pressure and oxidative stress in L-NAME induced hyper- tensive rats. Eur J Pharmacol 671, 87-94.

17. Shim, S. M., Im, K. H., Lee, W. Y., Kim, J. W., Shim, M. J., Lee, M. W. and Lee, T. S. 2003. Studies on immune-modulatory and antitumor effects of crude polysaccharides extracted from Paecilomyces sincluirii. Korean J Mycol 31, 155-160.

18. Shin, H. J., Oh, D. S., Lee, H. D., Kang, H. B., Lee, C. W. and Cha, W. S. 2007. Analysis of mineral, amino acid and vitamin contents of fruiting body of Sparassis crispa. J Life Sci 17, 1290-1293

19. Shon, M. Y., Seo, K. I., Choi, S. Y., Sung, N. J., Lee, S. W. and Park, S. K. 2006. Chemical compounds and biological activity of Phellinus baumii. J Korean Soc Food Sci Nutr 35, 524-529.

20. Soda, K., Tanaka, H. and Esaki, N. 1983. Amino Acids, Biotechnology. In Rehm, H. J. and Reed, G. (eds.), Vol. 3, pp. 479, Verlag Chemie, D-6940 Weinheim, Germany.

21. Suzuki, M., Arika, T., Ameriya, T. and Fujiwara, M. 1982. Cooperative role of $\mathrm{T}$ lymphocytes and macrophages in antitumor activity of mice pretreated with schizophyllan. Jpn $J$ Exp Med 50, 59-65.

22. Yamamoto, K., Kimura, T., Sugitachi, A. and Matsuura, N. 2009. Anti-angiogenic and anti-metastatic effect of $\beta-1,3-$ D-glucan purified from hanabiratake, Sparassis crispa. Biol Pharm Bull 32, 259-263.

\title{
초록 : 꽃송이버섯(Sparassis crispa) 추출물의 면역세포 활성화 및 항암 효과
}

\author{
김인규 ${ }^{1} \cdot$ 윤영철 $^{2} \cdot$ 신용철 $^{2} \cdot$ 유지윤 $^{1 *}$ \\ ( ${ }^{1}$ 경상대학교 자연과학대학 미생물학과/생명과학연구원, ${ }^{2}$ 아미코젠(주))
}

꽃송이버섯(Sparassis crispa)은 항암 및 면역증강 효과가 뛰어나다고 알려져 있는 베타-글루칸의 함량이 건조 중량의 $40 \%$ 이상인 것으로 보고되고 있는 산림버섯이다. 일반적으로 버섯에서 추출한 베타-글루칸의 면역활성 및 항암 효과는 널리 알려져 있는 반면 꽃송이버섯 유래의 베타-글루칸에 의한 대식세포의 활성화 기작 및 자실체 추출물에 의한 항암 효과는 아직 보고되지 않았다. 본 연구에서는 꽃송이버섯 유래 베타-글루칸의 면역활성 효과를 확인하고자 마우스의 대식세포인 Raw 264.7 cell을 이용하였으며, 베타-글루칸 처리시 TNF- $a$ 와 interleukin-1 $\beta$ (IL-1B)와 같은 사이토카인의 발현 및 분비가 증가됨을 확인하였고, 이러한 과정에 필수적인 역할을 담당하는 전사 인자인 NF-kB가 활성화됨도 확인하였다. 뿐만 아니라 꽃송이버섯 추출물 처리 시 TNF-a의 분비가 증가됨과 함께 in vivo에서 암의 성장을 억제하는 기능이 있음을 확인하였다. 이러한 결과들은 꽃송이버섯이 면역활성을 증가시켜 암의 성장을 억제하는 건강 기능성 식품으로서의 개발 가능성이 높음을 의미하는 것이다. 